\title{
Context and Agency: Complementarity and Interactivity
}

Jan Elen, KU Leuven, Belgium

\begin{abstract}
In the article 'Factors predicting online university students' use of a mobile learning management system (m-LMS)', Joo, Kim and Kim (2016) explain actual usage of a mobile learning management system by looking at continuance intention, satisfaction, perceived usefulness, perceived ease of use and expectation confirmation. Perceived usefulness seems to play a pivotal role. In this reaction, it is argued that their study can be approached from to complementary and interacting perspectives: context and agency.
\end{abstract}

\section{Introduction}

In the article 'Factors predicting online university students' use of a mobile learning management system (m-LMS)', Joo, Kim and Kim (2016) explain actual usage of a mobile learning management system by looking at continuance intention, satisfaction, perceived usefulness, perceived ease of use and expectation confirmation. They contribute to our understanding by integrating different theoretical models and especially by considering actual usage data. Their paper reveals the complementarity and interaction of two perspectives: one that considers the educational context, c.q. a mobile learning management system and a second one that stresses agency, c.q. the use of that environment by students. Both perspectives are complement each other and with each other.

\section{Context}

As part of the research on mobile learning, Joo et al. help to understand the use of mobile devices. Recent events have revealed the importance of these devices as contexts for learning. Mobile devices have major affordances (see Squire \& Klopfer, 2007). The COVID19 crisis has immediately revealed two assets: portability and availability. Portability has allowed students to attend school from home. It has been proved that mobile devices can carry education. Instead of obstructing and deviating from acquiring learning outcomes in formal education, it enables education in difficult times. That is revealing as for instance mobile devices are banned from schools in France since September 2018. Availability is another major asset. Mobile devices are everywhere, their penetration is nearly absolute and this in quasi all countries irrespective of their economic development (see a.o. Motlik, 2008). In recent months it was shown that not all students may have computers, laptops or tablets at home but they all seem to have cell-phones. Thanks to those mobile devices education could be made available to all students and learning has never stopped (see for testimonies: https://en.unesco.org/covid19/educationresponse/learningneverstops/testimonies). A teacher in an education center In Flanders reported that she corresponded with her students, mostly with a migration background, through WhatsApp. In the absence of specifically targeted software WhatsApp functioned as the major learning management system. 
Mobile devices make education accessible anytime and anywhere. That is highly attractive, there might also be a downside as all limitations seem lifted. Teachers can give (additional) tasks 24/7, students can call upon teachers $24 / 7$. The school never closes. It is fascinating to observe that mobile devices reveal that education is not restricted to what happens at school, at the same time it highlights the relevance of schools as a safe delineated place and time totally dedicated to education (Masschelein \& Simons, 2013).

Joo et al. investigated factors that affected students' use of a mobile learning management system. They focus on student factors (see agency). Focusing on the environment, it seems equally relevant to also study the factors that determine usability and usefulness. What features make it easy to use, what aspects make it useful? This is a plea for more attention in educational research on ergonomy. Norman's 'The design of everyday things' (1988) remains a 'must-read' for all educational professionals and researchers. Another point of attention remains usefulness. Usefulness is probably determined by functionality, it remains to be repeated that functionality in educational environments is not in as much determined by the technology used as it is by the constructive alignment between needs of students, instructional interventions and educational goals (Biggs \& Tang, 2007). In other words, while video-based lectures might be easily transported by mobile devices, it is not self-evident that video-based lectures are the most optimal educational approach for all students and/or for all educational goals.

\section{Agency}

By focusing on factors that affect student's use of a mobile learning management system Joo et al. stress the important and often neglected agency of students. Whether or not a system is used and how it is used, is not only determined by the system, the learner also plays an enormous role. Past research has revealed the importance of cognitive, metacognitive as well as affective factors to understand students' agency (e.g., Sarfo \& Elen, 2007). The COVID19 disruption has shown our view has probably been a bit limited.

The COVID19 disruption has chased pupils out of schools. Luckily most of them (see penetration) could use their mobile devices to keep in touch with education. At the same time, it has become crystal-clear and unfortunate that this is not the case for all students and that both the quantity and quality of use of educational opportunities is also determined by socio-economic factors (not all students do have access to well-functioning internet), socio-cultural factors (not all parents have to luxury to be able to support their kids' learning) and psychological factors (not all students could learn as they got stressed by insecurity, by fear, by ...).

While Joo et al. point to important aspects, the crisis has indicated that there is a need to look even broader. Understanding the use of mobile devices especially outside a protective environment as a 'school' requires studies that are fully ecologically valid.

\section{Conclusion}

The study of Joo et al. reveals the complimentary importance of context and agency. In confrontation with the disruptive covid19 context, it has also become clear that by bringing education into 'the world', we must not be surprised that 'the world' also affects education. That must not be a problem, it does remind us about the need to continuously acknowledge -both in practice and in research- the complexity of education. 


\section{References}

Biggs, J., \& Tang, C. (2007). Teaching for Quality Learning at University. Berkshire, England: Open University.

Joo, Y. J., Kim, N., \& Kim, N. H. (2016). Factors predicting online university students' use of a mobile learning management system (m-LMS). Educational Technology Research and Development, 64, 611630.

Masschelein, J., \& Simons, M. (2013). In Defence of the School. A Public Issue. Leuven, Belgium : Education, Culture \& Society Publishers.

Motlik, S. (2008). Mobile learning in developing nations. International Review of Research in Open and Distance Learning, 9(2). https://doi.org/10.19173/irrodl.v9i2.564

Norman, D. (1988). The Design of Everyday Things. New York : Currency and Doubleday.

Sarfo, F.K., Elen, J. (2007). The moderating effect of instructional conceptions on the effect of powerful learning environments. Instructional Science, 36 (2), 137-153. doi: 10.1007/s11251-0079023-8

Squire, K., \& Klopfer, E. (2007). Augmented reality simulations on handheld computers. Journal of the Learning Sciences, 16(3), 371-413. 